\title{
Considerations of Immediate Side Shifts
}

\author{
Kazuhiro Yazawa, D.D.S. \\ Tokyo/Japan
}

It is not alway s easy to discriminate immediate side shift from the tracing line which appears on the pantograph. Guichet did not sufficiently explain how to interprete early side shift and distributed side shift. However, Lundeen in 1973 stated that all the shifts other than progressive side shift contain immediate side shift.

As a method to quantitatively determine immediate side shift, the conventional method of adjusting the Denar D5A articulator with Denar pantograph was slightly modified. Specifically, the author first adjusted progressive side shift and the immediate side shift. Thus, immediate side shift was quantitatively determined from the conventional line representing distributed side shift.

During the adjustment, the opposite sylus was kept on the working line. When it is difficult to read immediate side shift in the non-working line, you can carefully observe the initial movement of the working line. Then a non-smooth blending will be observed and immediate side shift can bè read.

The author has experienced several cases in which early side shifts changed into progressive side shifts in the course of follow-up after mouth rehabilitations. In the case of a patient with distributed side shifts, early side shift also changed into progressive side shift when slide in centric was removed. When side shift is small, it may be possible to eliminate immediate side shift by the removal of premature contact, modification of incisal guidance, assurance of centrice stop, and establishment of vertical stop.

はじめに

イミディエート・サイド・シフトをバントグラフト: で解読することは、必しも容易ではない。明睢にイミ デイエート・サイド・シフトと解かるものもあるが、 反面、これをイミディエート・サイド・シフトと読ん でよいかどうか、形の点からも、量的にも判断に苦し むものも意外に多い。

そこで本論文ではDenarのバントグラフによるト鄂 運動記録をDenar D 5 A 咬合器に库現与る際に普通… 般に行なわれている調節方法に、若下の順序の変更を Treasurer, International Academy of Gnathology Asian Section.

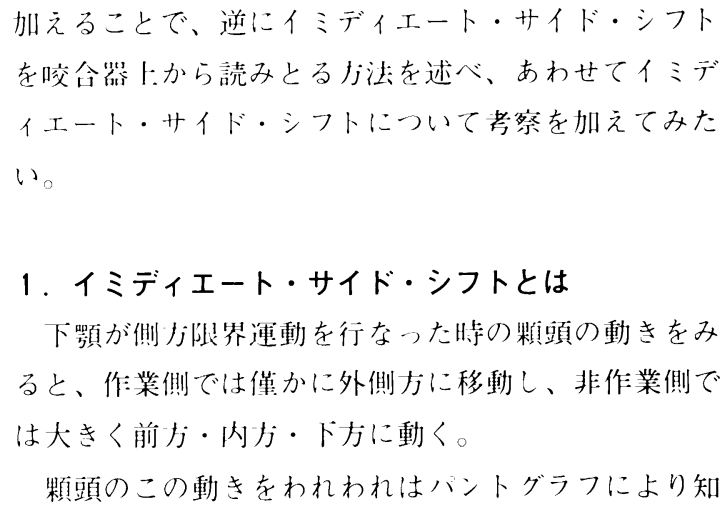




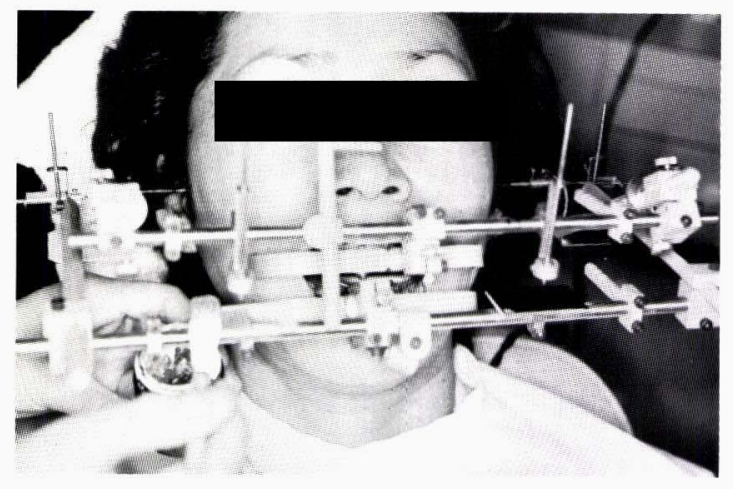

Fig. 1 装着されたStuart パントグラフ。

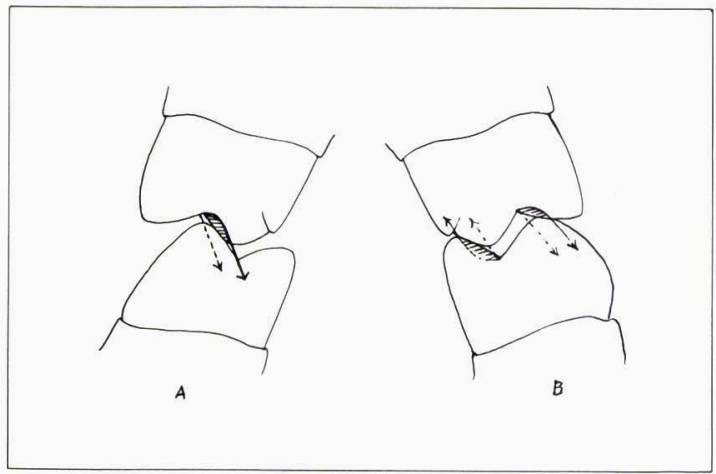

Fig. 3 イミディエート・サイド・シフトと咬頭干渉のあらわれ る位置。点線の知印はイミデイエート・サイド・シフトがない場 合の方向。A は非作業側、B作業側。

ることが出来るが(Fig. 1)、連動の開始と同時に側方 運動を素直に行なう場合と(Fig. 2 A)、僅かではある が両側顆頭が一たん側方に「横すべり」した後に、本 来の側方連動をとる場合とがある(Fig. 2 B)。後者にみ られる初期横すべりをイミディエート・サイド・シフ 卜と呼び、末次教授は「即時側方転換」と訳している。 このイミデイエート・サイド・シフトが問題になる のは、横すべりそのものは僅かの運動量であるが、

(1) 中心位からの動きの初期に出現する。

(2) その間に上・下歯牙間に接触滑走が行なわれる。

寸なわち、中心位における早期接触をおこし、その 結果、咬合性外傷やブラキシズム、顎関節の機能障碍 等をおこす原因となりかねないためである。

そこでイミディエート・サイド・シフトにたいする、 われわれの対処の仕方が問題になる。もしもイミディ エート・サイド・シフトを消すことが出来るようなら、 その努力をしてみることである。四３にみられる斜線

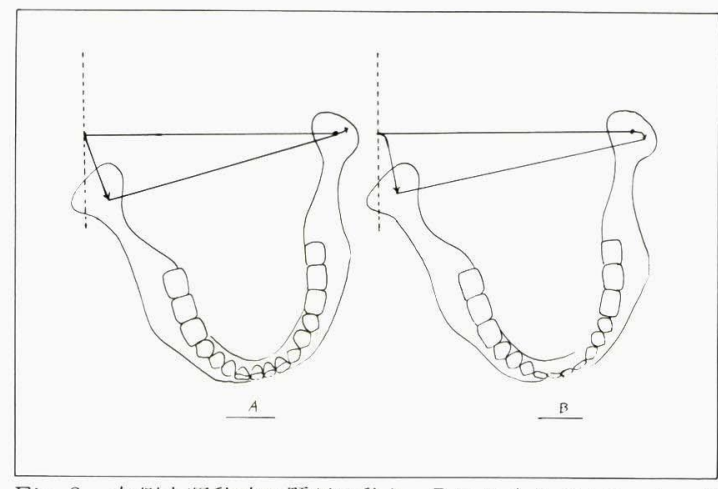

Fig. 2 左側方運動時の顆頭の動き。Bにはイミディエート・サ イド・シフトがある。

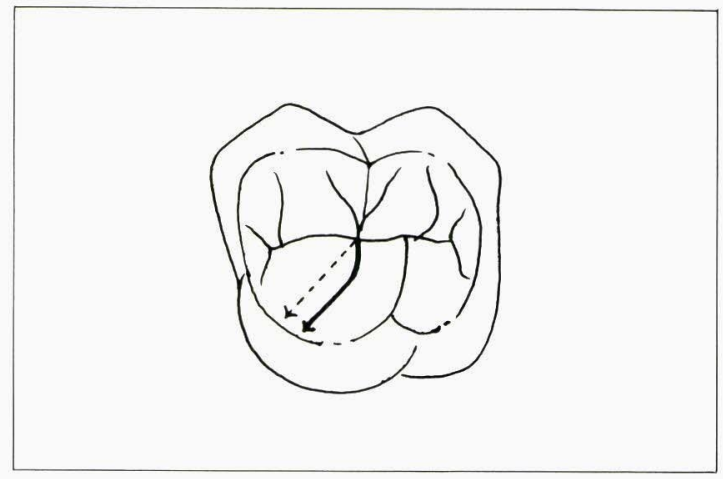

Fig. 4 咬合面にあらわれる干渉部分。

部分が中心位における早期接触部分であって、咬合調 整をすることでこの斜線部分を切削して、中心溝の巾 をひろげ、Tip to Fossaの関係を与えてみる。また 切料路を修正してみる。テンポラリー・クラウンによ つて咬合在改善してみる等があげられる。しかし、・ 方では全く消すことの出来ないイミディエート・サイ ド・シフトもあって、この場合、非作業側では咬合面 溝の走行力向にも影響を与える。Fig. 4 の実線部分が イミディエート・サイド・シフトに影響される部分で あって、同困の点線の矢印と比較した場合、可成りの 位置的なずれが見られる。一方、作業側では、その運 動の総量および動きの方向が少ないために、非作業側 にみられるような明膫な違いは見当らない。

\section{Guichetによるサイド・シフトの分類}

Guichetはパントグラフ上にあらわれた非作業側の 軌跡分析して、中心位からの最初の $4 \mathrm{~mm} の$ 動きによ 


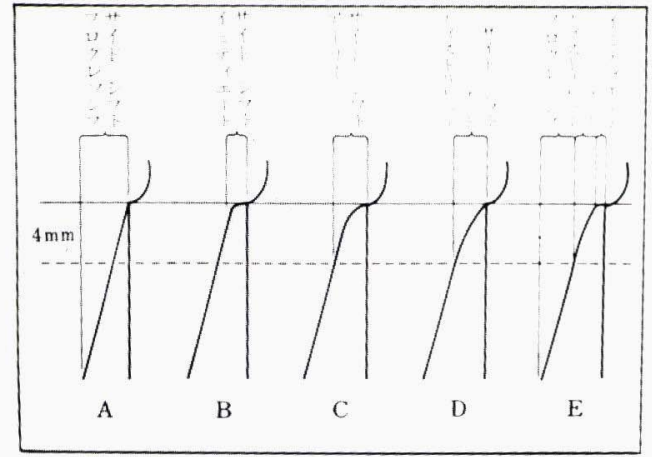

Fig. 5 ギシェーによるサイド・シフトの分類。

つて、Fig. 5 のようにその形態を 5 段階に分類してい る。このうちでイミデイエート・サイド・シフトと名 付けられているのは、B执ざEである。なお、Eは 各種形態の混合形である。

Guichetの説明によればCのアーリー・サイド・シフ トは $4 \mathrm{~mm}$ の初期運動のなかでも特に、その最初の部分 に運動の大半が集中古る場合を指し、Dのディストリ ビューテッド・サイド・シフトでは $4 \mathrm{~mm} の$ 間で大半の 連動が均等に配分されている場合を指すという。した がって、アーリー・サイド・シフトのカがディストリ ビューテッド・开イド・シフトよりもはるかに横す心゙ りの度合が強く、イミディエート・サイド・シフトに 近いわけである。Denar 咬合器ではこのアーリー・サ イド・シフトとディストリビューテッド・サイド・シ フトの 2 種類の形に相当するメディアル・ウォールが 作られており (Fig. 6)、咬合器を調節する際にこれら を装着することで、より一層、パントグラフの軌跡に 合致するようにしてある。このことから、咬合器にあ るイミディエート・サイド・シフトの調節機構は、Fig. 7 Bのイミディエート・サイド・シフトおよび、Eの 混合形に適用されることがわかる。しかし、実際には これらの形態の中間形や移行形もあって、明確な分類 をするのは必しも容易ではない。一体、どの動きから をイミディエート・サイド・シフトの調節に組み人れ たらよいのか、従来この点が明瞭でなかったように思 われる。したがってその判断は各自の臨床的経験に委 ねられていた。

なお Guichetの考えのなかで、サイド・シフトに関

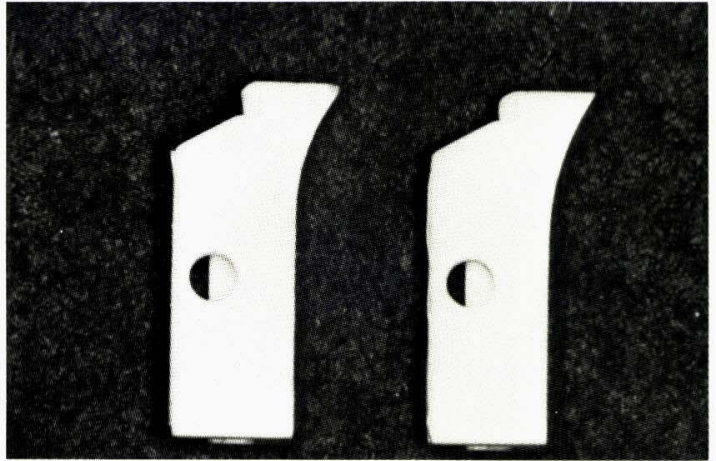

Fig. 6 Denar咬合器専用のメジアル・ウォール。パントグラフ の非作業ラインにあった方を使用する。左はアーリー・サイド・ シフト用。右はディストリ・ビューテッド・サイドシフト用。

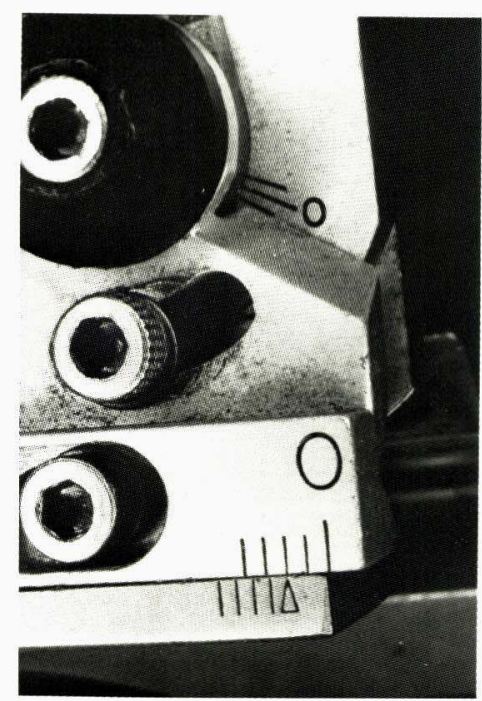

Fig. 7 Denar咬合器の調節装置。一番下の留ネジはイミディエ 一ト・サイド・シフトの調整、中央のネジはプログレッシブ・サ イド・シフトの調整、ト部のネジはリアー・ウォールの調整を行 なう。

する次の 2 点は重要であるので書き加えておく。

(1) 非作業側ラインの最初の $4 \mathrm{~mm}$ をぎた後は、殆ん どが直線の形態をとる。

(2) 咬合が不完全になるにしたがって、サイド・シフ トの量が増加する。

これらの Guichetの考えの延長上に、次に述べる19 73年の Lundeenの有名な学説が現われる。 


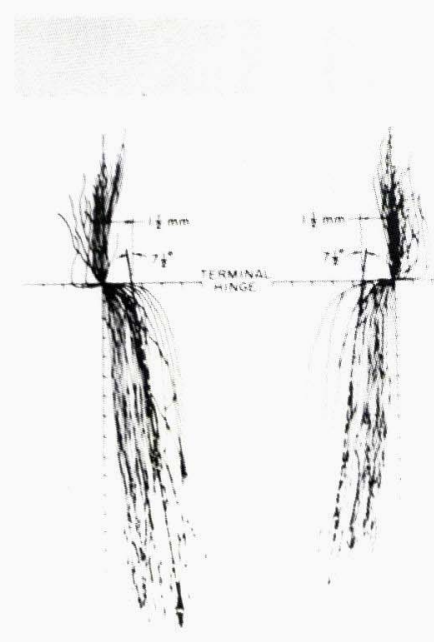

Fig. 8 ランディーンの実験結果。50名の被験者の左右側方限界 連動の水平面投影が集計されている。

(from. Gibbs, C. H., etc : J. Prosthet. Dent 37 : 388, 1977 )

\section{3. ランディーンのイミディエート・サイドシフトに}

\section{ついての見解}

1973年、J.P.D.に発表された論文である。Lundeen はLeeの下顎運動記録装置を使用して、50名の被験者 の下顎運動をそのプラスチック・ブロックのなかに削 りこみ、一定の条件のもとで比較検討してみた。その 結果、側方運動における被騃者個々の違い、従来いわ れて来たベネット角の違いは、各白の非作業側顆路全 体の違いではないことがわかった。すなわち、Fig. 8 にみられる側方運動の水平面投影において、非作業側 顆路の違いは中心位からの連動初期にあらわれる顆路 の弯曲の差、いいかえれば、連動初期にあらわれるイ ミディエート・サイド・シフトの違いによるものであ つて、その後の顆路はほぼ平行に近いことを発表した。 筆者の経験でもこの平行部分の顆路（プログレッシブ ・サイド・シフト) は、 5 〜 7 である。

この非作業側の弯曲の部分をよくみると、上述のGuichet が分類した形態がみな含まれている。Lundeen の見解にしたがえば、プログレッシブ・サイド・シフ トを除いた他の形態はすべて、イミディエート・サイ ド・シフトに包括されることになる。にもか、わらず、 筆者などが長い間、ディストリビューテッド：サイド ・シフトとアーリー・サイド・シフトの中間形を、イ

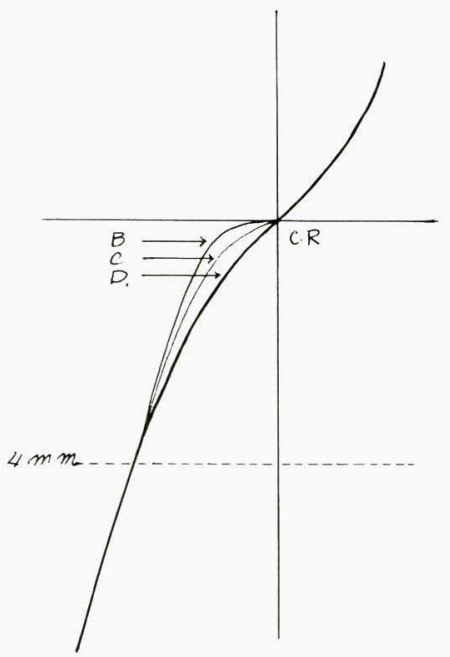

Fig. 9 ギシェ一の分類から、Bのイミディエート・サイド・シ フト、Cのアーリー・サイド・シフト、Dのディストリビューテ ッド・サイド・シフトを重ねあわせた。

ミディエート・サイド・シフトとは別個のものとして 理解しまた取扱って来たのは、上述の Guichetの分類 に影響されていたためであって、真横に動くものがイ ミディエート・サイド・シフトであると戦純に考えて いたことによる。

Lundeenのこの見解を咬合器に表現したのが、Denar Mark II、Occlusomatic 等である。側方チェック ・バイトで側方顆路を調節する場合に、あらかじめ心 ネット角を一定角度 $\left(5 \sim 6^{\circ}\right)$ に設定しておいて、残余 の動きはイミディエート・サイド・シフト調節機構で 行なうようになっている。したがって、 $5^{\circ ま た は ~} 6^{\circ}$ のプログレッシブ・サイド・シフト以外の運動はす心゙ て、イミディエート・サイド・シフトを含むものとし て取扱われることを意味する。

4. Denar D 5 A咬合器によるイミディエート・サイ ド・シフトの調節

パントグラフを用いて Denar咬合器を調節する手順 は以下のように示されている。
A 前方顆路の調節
(B) イミディエート・サイド・シフトの調節
C) プログレッシブ・サイド・シフトの調節
Dリアー・ウォールの調節 


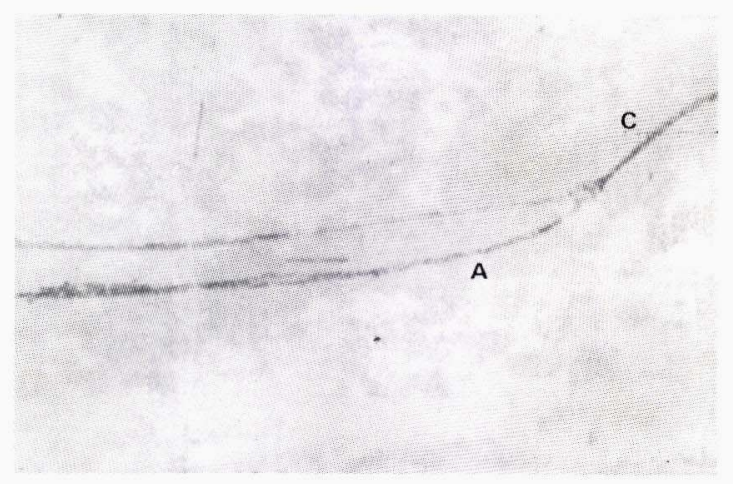

Fig. 10 右後方水平面描記板。 $\mathrm{A}$ 注非作業ライン。Cは作業ライ 。

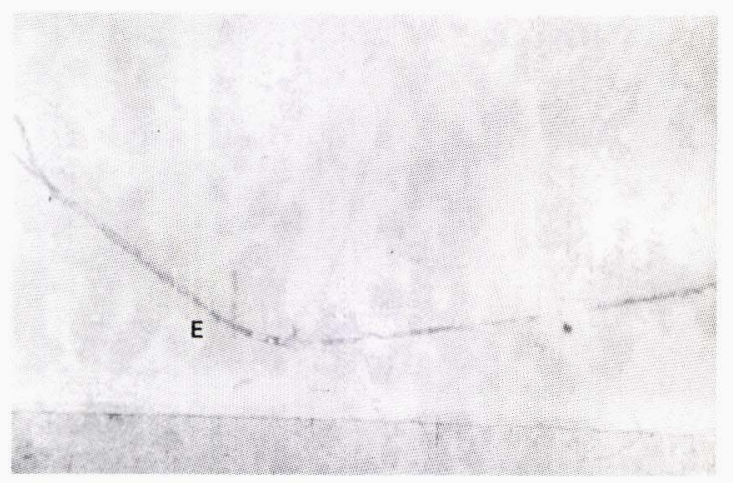

Fig.12 右前方描記板。Eは非作業ライン。

E 垂直顆頭軸の調節

F 矢状面側方顆路とトップ・ウォールの調節

この手順のうち、○印を付した(B)と(Cの順序は、前 章において述べたDenar Mark IIの調節順序と逆であ る。

まずイミディエート・サイド・シフトを量的に決定 し、しかる後にプログレッシブ・サイド・シフトの調 節を行なう。このことは、パントグラフトの初期運動 をイミディエート・サイド・シフトと㳘むか読まめか、 またイミデイエート・サイド・シフトとして㳘んだ場 合にはどの程度の量を咬合器に与えるか等の問題が、 術者の判断に一任されるため、多分に術者の主観的選 別に委ねられることになる。決して機械的な、または 客観的な計測によるものではない。Fig.9に見るよう に、ディストリビューテッド・サイド・シフトから、 アーリー・サイド・シフトを経てイミディエート・サ イド・シフトに致るまでの間に存在する無数の中間移

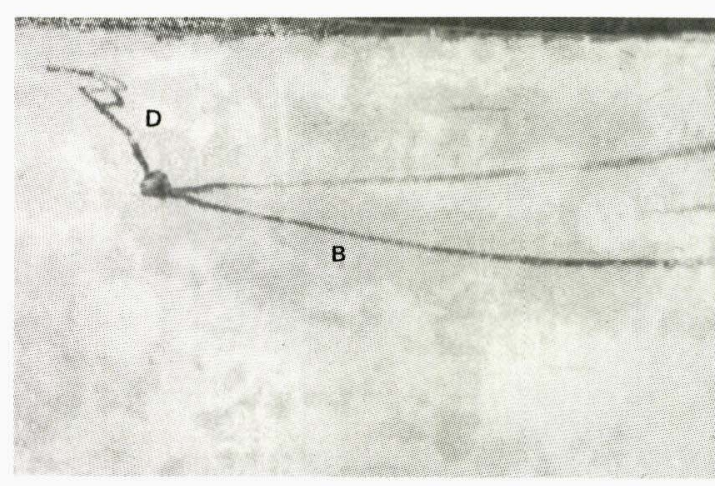

Fig. 11 左後方水平面描記板。Bは非作業ライン。Dは作業ライ y。

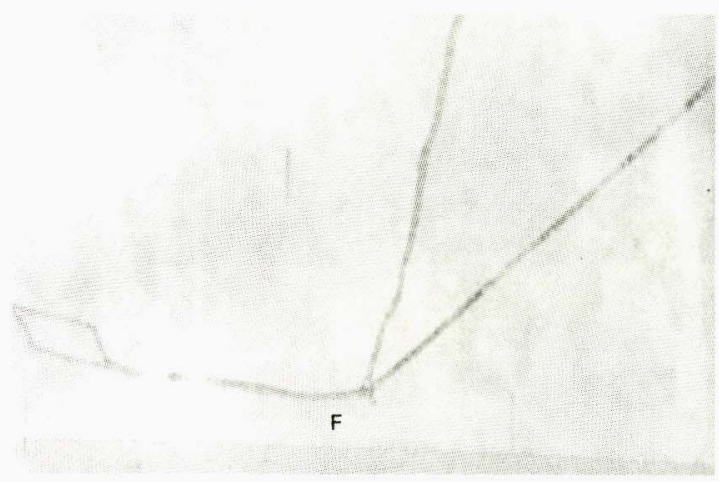

Fig.13左前方描記板。Fは作業ライン。

行形の処理にとまどいつぶけてきた。

そこで調節の順序を(C)から(B)、すなわち Mark II の方法に変更してみた。以下にその一連の操作を写真 を追つて説明する。

左:盾の後方水平面軌跡の非作業ラインを比較すると、 Fig.11の左後方描記板の非作業側ライン B はブログレ ッシブ・サイド・シフトであるのに対し、Fig.10右後 描記板のAは、ディストリビュテッド・サイド・シ フトとアーリー・サイド・シフトの中間移行形である。 前う描記板においてもこのことは理解される。Fig. 12右前う描記板の非作業側ライン E および、Fig.13左 作業側ラインFは、それぞれアペックスからゆるい力 一ブを描いている。

まずイミデイエート・サイド・シフト調節ネジをゆ るめた後に、Fig.14Gにみられる在後方描記板のプロ グレッシブ・サイド・シフトのはじまる位置に描記針 を一致させる。このときFig.15では左後方描記板の作 


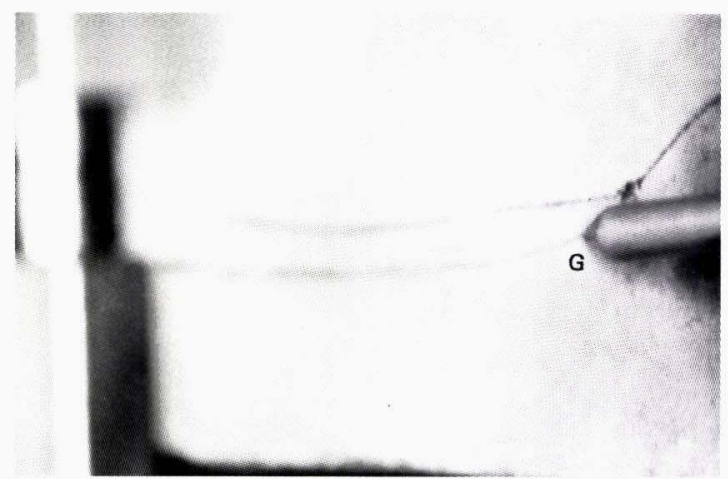

Fig.14 右後方描記板上で、プログレッシブ・サイド・シフトの はじまる位置にあわせた描記針。イミディエート・サイド・シフ ト調節ネジはゆるめてある。

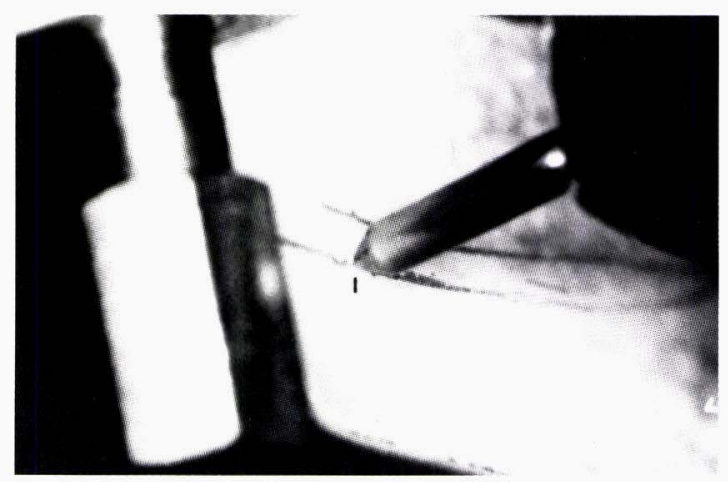

Fig.16 右後方描記板のプログレッシブ・サイド・シフトの末端 にあわせた描記針。ベネット角をきめる。

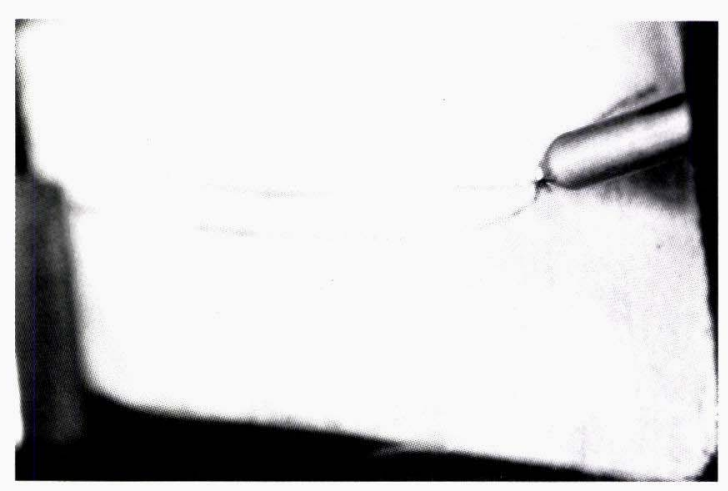

Fig.18 描記針を中心位へもどす。

業ライン Hに描記針が乗つている。このFig.15につい ては、Fig.23と共に、この章の最後のところで説明し たい。

Fig.16Iにみられるように、右非作業ラインの末端ま で描記針が線上を走るように、プログレッシブ・サイ

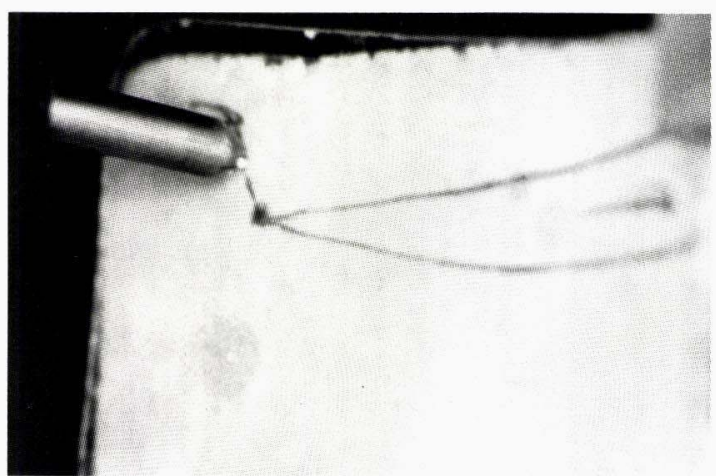

Fig. 15 左後力描記板の作業ライントでは、Fig.14に相当する位 置に描記針がのっている。

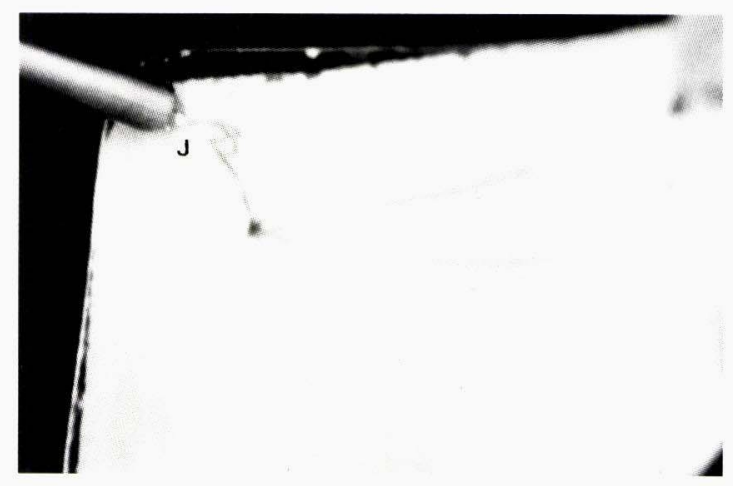

Fig. 17 左後方描記板でも作業ラインの末端に描記針がある。

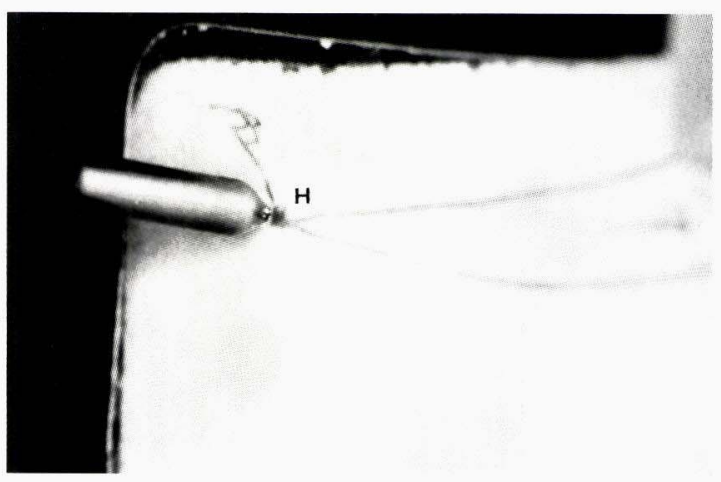

Fig.19描記針を中心位へもどす。

ド・シフト調節機構を調整する。Fig.17 J でも左作業 ラインの末端に描記針が位置している。このようにし て決定されたプログレッシブ・サイド・シフトは大体 において 50または7゚になることが多い。このことは Lundeenの見解と一致する。 


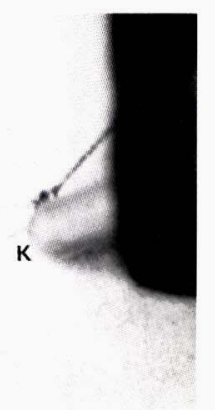

Fig. 20 右後方描記板上で、描記針を真横にずらし、プログレッ シブ・サイド・シフトを延長した仮想線と交わる位置でとめる。 イミディエート・サイド・シフトの調節ネジを締める。

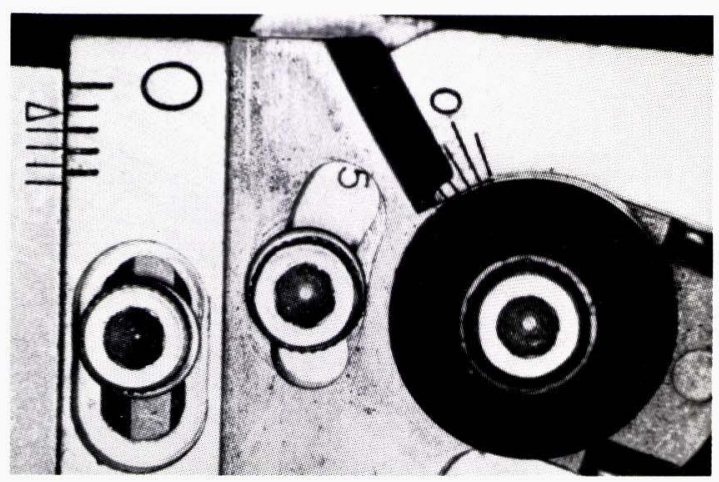

Fig.22このようにして調節されたDenar D 5 A の調節機構。

次にイミディエート・サイド・シフトの量を決定す るために、Fig.18、19の如く、まず描記針を中心位の 位置にもどす。

次にFig.20のごとく、プログレッシブ・サイド・シ フトを延長した仮想線との交点 $\mathrm{K} に$ に描記針を横す心゙り させる。この位置で描記針をとめて、イミディエート ・サイド・シフトの調節機構を固定し、移動量をしら ベる。この場合、ギシェーの分類の何形に属するかは、 一切問題にしない。Fig.21はFig.20の状態を模形図に したものである。点 K はFig.200描記針の位置、すな わちイミディエート・サイボ・シフトを決定する位置 であり、点Gと I は Fig.14およびFig.16のプログレッ シブ・サイドヌシフトのはじまる位置とその末端を小 している。

このようにして調節されたDenar咬合器の右側ホッ サ・八ウジグがFig.22である。プログレッシブ・サイ

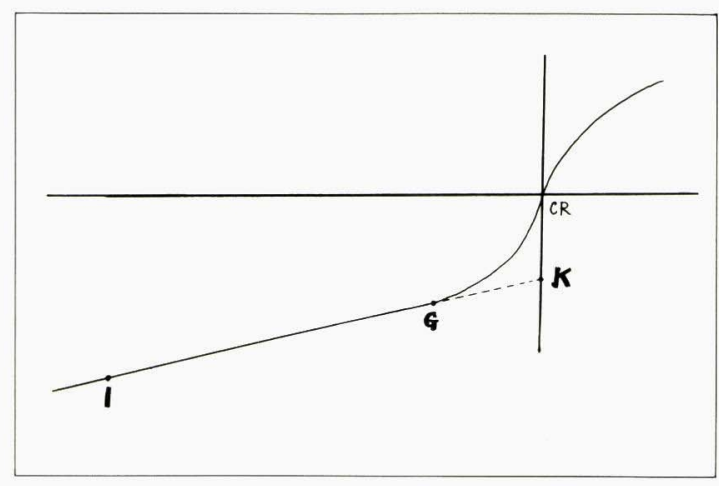

Fig.21 Fig.20の模型网である。G、Iはプログレッシブ・サイ ド・シフトを決める位置。Kはイミディエート・サイド・シフト を決定する位置。

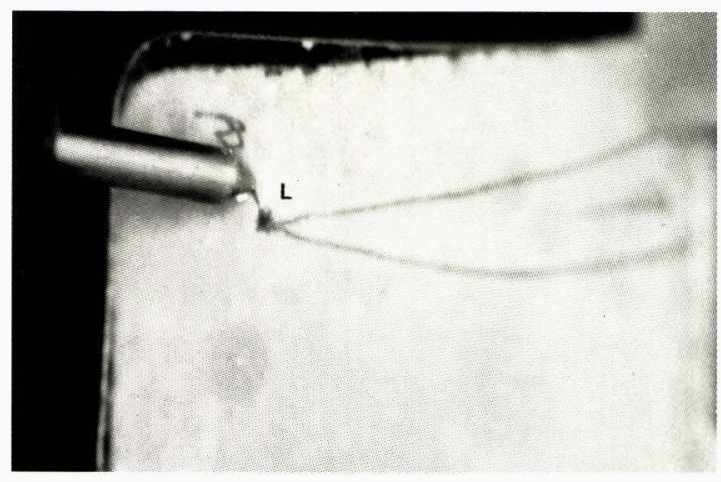

Fig.23イミデイエート・サイド・シフトが決定された時点での、 左後方描記板トの描記針の位置。この位置は重要なので記憶す心゙ きである。

ド・シフトは6゚を指し、イミディエート・サイド・シ フトは $1.2 \mathrm{~mm}$ 寺小している。以上からみて、最初にデ イストリビュテッド・サイド・シフトとアーリー・サ イド・シフトの中間形であったラインが（Fig.10）、意 外に $1.2 \mathrm{~mm}$ に挨よ゙イミディエート・サイド・シフト 在持っていたことを知ることが出来る。

この調節が終つたら反対側にある作業ラインの初期 移動の軌跡と描記針が一致するかどうかの確認をする。 Fig.23Lはその状態を示している。すでにFig.20、21 でみたように、仮に非作業側のイミデイエート・サイ ド・シフトに相当する部分の軌跡と描記針が一致しな い場合でも、い、かえれば、Guichet の云う over compensationになった場合でも、作業側では一致し易い。

このことから以下の事柄が理解出来る。非作業側に おいてイミディエート・サイド・シフトかどうか決め かねたら、反対側の作業ラインを注意深く観察すると 


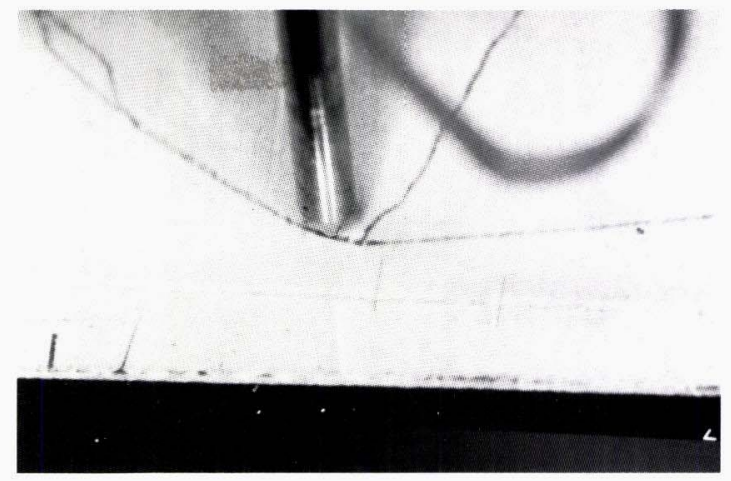

Fig. 24 右前方描記板の非作業ライントでも、等鱼のイミデイエ ート・サイド・シフトの位置に描記針がとまっている。

意外に解読が容易になるということである。

これはパントグラフを支える上・下クラッチが、七 ンター・ベアリングによって接しているので、両側 4 ヶ所の水平面描記板にイミディエート・サイド・シフ 卜が等量に記録されるためである。したがって、Fig. 24 の如く存前方描記板の非作業ラインにも等量の位置 でスタイラスがとまっている。しかし、後方描記板の 作業ラインのみは以後の動きが僅かであるために、イ ミディエート・サイド・シフトとの接続が一種のギコ 千なさをもって描かれることが多い。すでに Fig.15、 17、19、23で見てきたように、左後方作業ライン各久 テップで描記針は正確に線上にあった。こ、で問題に したいのは、この各ステップの描記針の位置をFig.11 の原形の作業ラインの上に想定してみると、作業ライ ンにおける初期運動がギコチなさをもっており、その 後、次の運動に移行していくのが理解出来る。すなわ ち、Fig.15は平衡側のプログレッシブ・サイド・シフ トのはじまる位置、Fig.23は同じくイミディエート・ サイド・シフトの終る位置に相当し、その 2 点のわず かなズレの間で、このギコチなさが現われるのである。

\section{5. 若干の症例の説明}

(1) 症例 A (Fig.25)は、左右の非作業ラインが典型的 なプログレッシブ・サイド・シフトである。このよう な症例では補緅物製作に際して、半調節性咬合器の使 用で充分である。

(2) 症例B (Fig.26)は、症例 A と非常に似た軌跡であ る。見すごすと左右ともにプログレッシブ・サイド・

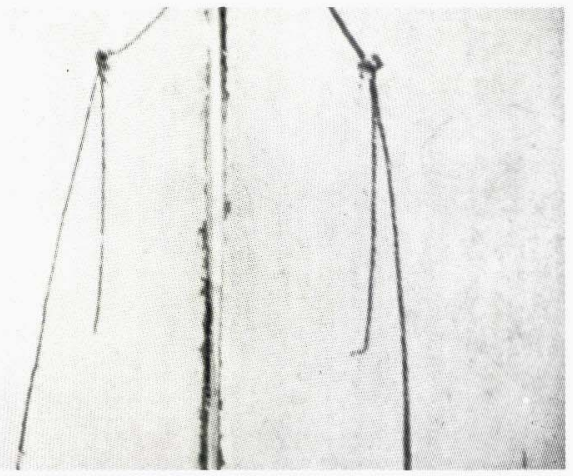

Fig. 25 症例 $\mathrm{A}$ 。左右とも典型的なプログレッシブ・サイド・シ フトである。

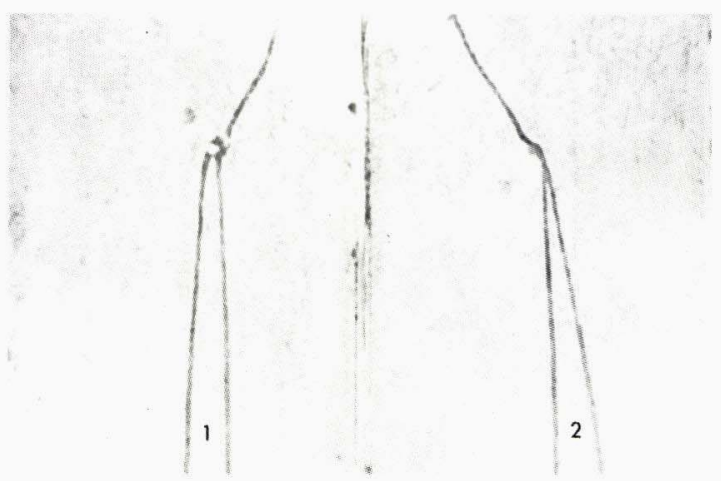

Fig. 26 症例 B。症例 A と似ているが、左非作業側ライン ( 1 )に イミディエート・サイド・シフトがある。それと等量のサイド・ シフトが右作業側ライン (2)の初期に観察される。

シフトとして扱いかねない。しかし注意深く見ると左 非作業ライン（向って左側）には僅かなイミデイエー ト・サイド・シフトが観察される。だが描記針によっ て出来た凹みのために明瞭ではない。そこで右作業ラ イン（向って右側）の初期連動をしらべると、対応し た部分に等量のイミディエート・サイド・シフトのギ コチない接繶が読める。

(3) 症例 $\mathrm{B} の$ 術前のパントグラフと、オーラル・リハ ビリテーションを行なった後 4 年目のパントグラフと を比較し易いように、左側の軌跡はFig.27に、右側の 軌跡はFig.28にまとめてみた。各図の向って右側が術 前、左側が術後 4 年の軌跡である。上述した左非作業 ラインのイミデイエート・サイド・シフトは、 4 年後 には完全に消えている。逆にFig.28の2つの作業ライ ンを比較すれば、術前の軌跡にはイミデイエート・サ 

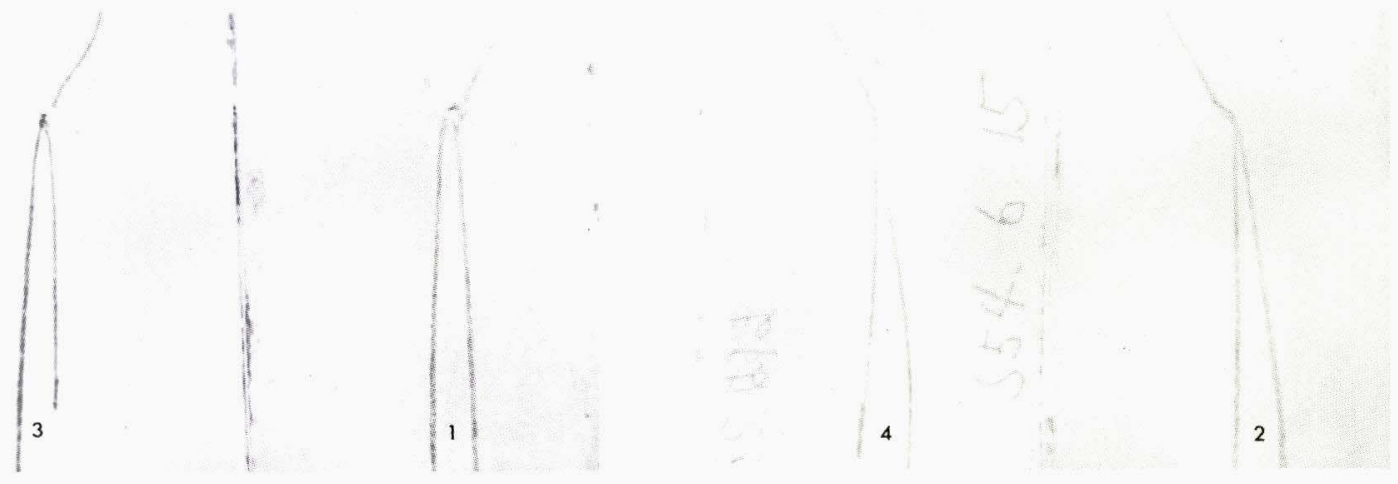

Fig.27.28 症例Bの術前と術後 4 年目の対比である。番号 1、2 はF ig. 26と同じもので術前の軌跡であり、3、4は 4 年後のものであ る。1のイミディエート・サイド・レフトが 3 では消えているのが観察される。

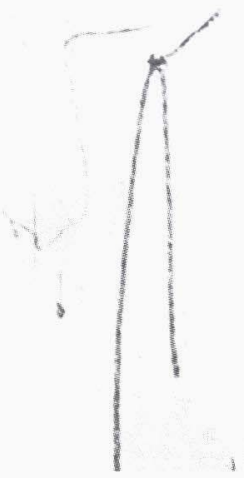

Fig. 29 症例 C。左非作業ラインにイミディエート・サイド・シ フトが見られる。右作業ラインのその部は描記針が跳んでいる。

イド・シフトが明確に読みとれる。

この経過観察からも解るように、イミデイエート・ サイド・シフトには、適当な処置を行なうことで消え るものがあること在理解すべきであろう。

(4) 症例C (Fig.29)でも同様に、左非作業ラインにイ ミディエート・サイド・シフトが読める。有作業ライ ンの対応寸る部分は描記針が跳んで空白になっている。 この症例では右側の上・下犬歯が切端咬合であって、 右側方運動は第 2 小臼歯によって行なわれている。

(5) 症例D（Fig.30）の非作業ラインはそれだけでは何 と読むか難しい。しかし左作業ラインには中心位から 僅かではあるが横ぶれがあり、右非作業ラインのふく らみはアーリー・サイド・シフトであることを物語つ ている。このような症例では中心位の早期接触を除去 すると、プログレッシブ・サイド・シフトに変ること

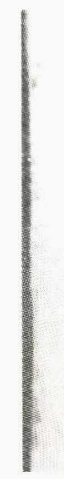

Fig. 30 症例D。左作業側の初期の動きを注意深く観察すると、 ギコチない動きが僅にある。作業側にあらわれたイミデイエート・ サイド・レフトである。

が多々ある

(6) 症例E (Fig.31) では限界運動と限界内運動がだぶ つて描記されている。この症例は臼歯部久損のま、永 年放㯰していたために、顎位が不安定になり、強いク リック音が聞かれる。

パントグラフによる記録採得には術者の誘導が必要 である。特にイミディエート・サイド・シフトは術者 のゆるい誘導、または患者による自発的な描記では現 われなかったり、量が少く出ることがある。また朝と 夕方では、朝の方がブラキシズムの影響が残っている ために、筋の spasum が強く出るという説もある。

(7) 症例Eに対して咬合調整を行なった後に、切歯路 を修正し、トリートメント・デンチャーを装着したの ち、4 ケ月日の記録がFig.32である。Fig.31のような 2 重の線は見られないが、形態そのものは恋っていな 


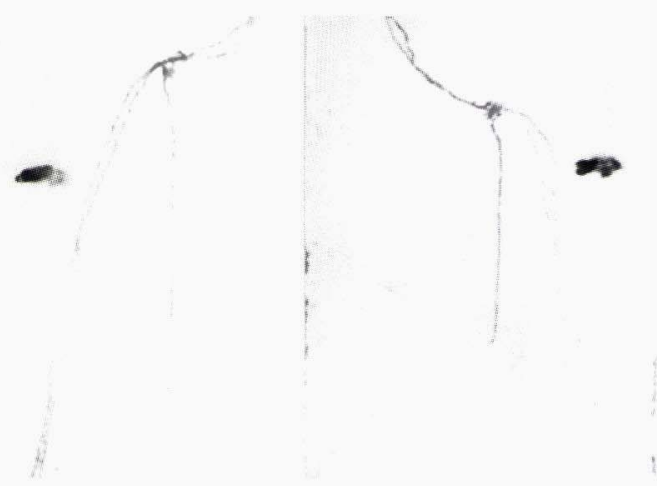

Fig. 31 症例 $\mathrm{E}$ 。限界内運動と限界運動が列記されている。舒運 動が定まらない症例である。

い。こうした症例では T M J のディスファンクション が考えられる。

(8) 症例F (Fig.33)では両側性にイミディエート・サ イド・シフトが見られるうえに、左右の非作業ライン の途中にはくびれが見られる。このような軌跡では顎 関節症または顎関節の器質的变化があると考えられる。 事実、この症例では長時間にわたつて開口を続けると T M J に激痛を訴えている。

\section{おわりに}

イミディエート・サイド・シフトに関しては、今H まだ不明な点が多い。原因にしても、筋の spasum、䩲 帯の伸張、筋覚記憶の記録、顎関節の器質的変化、顎 関節のディスファンクション等、いろいろいわれてい る。今後の研究をまたねばならない。

次に考えられる問題は、原因とつながる事柄ではあ るが、パントグラフに現われた軌跡をどのように受け とめるかということである。例えば、イミデイエート ・サイド・シフトは生理的なものか病的なものか。ま た、処置不能なのか可能なのか。また処置が可能なら、

\section{参考文献}

1) Guichet, N.F. : Occlusion. Anaheim, California, Denar Corporation, 1970

2) Lundeen, H.C.\& Winth, C.G. : Condyle movement patterns engraved in plastic blocks. J.Prosthet. Dent., 30:866 875, 1973

3 ) Gibbs, C.H.\& Derda, H.J. : A new articulator emphasizing centric occlusion and anterior determinants. J.Prosthet. Dent., 37:388, 1977

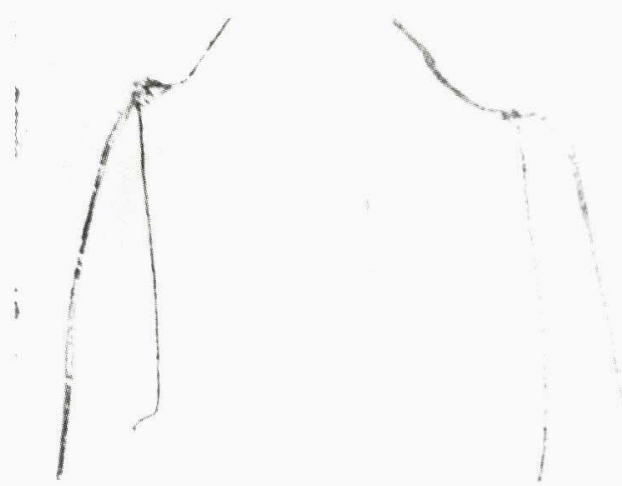

Fig. 32 症例Eに処置を行なって4ケ月日の記録である。二重の 線は見えないが、形態は変っていない。T M Jのディスファンク ションが考えられる。

Fig. 33 症例 $\mathrm{F}$ 。左右ともにイミディエート・サイド・シフトが 観察される。しかも、左右の非作業ラインの途中にくびれがある。 顎関節症または、顎関節の器質的変化が考えられる。

一体どのような形態のイミディエート・サイド・シフ トは消すことが出来るか。プログレッシブ・サイド・ シフトに変った場合、パントグラフ上の限界運動とは 何を意味するのか。課題は山積している。

しかし、それ以前の問題として、イミディエート. サイド・シフトはパントグラフ上にどのような軌跡を もつて現われるのか、その解読への試みを述べてみた。

4 ) Guichet, N.E. : Procedures for occlusal treatment. Anaheim, Denar Co., 1969

5 ) 末次恒夫、豊永美津系、田中良種：咬合・咬合論・咬合器; 補綴臨床、11(1), 4 47

6) 矢沢一浩：臨床からみたメタルボンドの問題点と対策 一一特に切歯路を中心に——日本㐘科評論., No.436:86 105, 1979 